\title{
テレフタル酸ジメチルエステルの合成について
}

\author{
テリレン原料として 一
}

Synthesis of Dimethylterephthalate

As the starting material of Terylene

桜 井亮 -* 小 方 和 夫** 板 垣 宏**
Ryōichi Sakurai,
Kazuo Ogata,

\section{I ま元がき}

合成俄維の中でその将来性を期待されているるのとし て，ナイロン，テリレン (デクロン)，アクリル系䄉維 の三つがあげられるが, これらいずれの合成䄉維てつい てもその原料問題は非常に重要であつて, 原料問題の解 決がこれら織維の工業化への大きな推進力となつて来た とも言えるのである。

現在我国で工業化が検討されているテリレンとついて る原料問題は深刻であつて特にテリレンの主原料である p-キシンンとエチレンを全面的飞石油化学工業飞仰がな ければなら状態からすれば, テリレンの工業化は石油 化学工業によつて決定されると言つてす過言ではない。

現状ではテレフタル酸シメチルエステル（DMT と略 す） は p-キシレンの液相空気酸化によつて合成される のが有利な様である。日本で石油化学工業によつて $p$ キシレンが得られる様になるとしてる，現在計画されて いる方法では $p$-キシレンは充分得られない様であり， p-キシレンと共に石油化学工業によつて多量に生産され るベンゼンやトルエンから安価な DMT が得られない ののであろろか。以下主としてベンゼン，トルエン及び pーキシレンを原料とする DMT の合成法について記し て見た。

\section{DMT 合成原料について}

DMT を合成する場合如何なる原料から出発すべきか kついては, ペトロケミカル, コールケミカル, 及びァ セチレン化学の工業的基盤基づいてすでに多くの綜説 があり熟知の事であるが, 一応順序として簡単にふれて 見る。

現在に於てはコールケミカルは乾溜工業の副産物処理 的な性格を持ち、コークス工業の現状から見て一応の限

*帝国人䅌企画部 $* *$ 帝国人絹研究所
界に達したものと考えられ，石炭から分雕されたベンゼ ン,トルエン, 及びキシレンにテリレンの原料を新たに 求める事は極めて困難であると思われる。特に我国の場 合, 石炭系のキシレンは年産 $1000 \mathrm{t}$ 程度であつてその 中の $p$-キシレンを全部分離し得たとしても $200 \mathrm{t}$ 位で 問題沈ならないのではなかろらか。しかし近時コールケ ミカルとして芳香属成分を石炭から合成する研究が活発 飞行われ，アメリカに於ては各種石炭のアルカリ性空気 酸化によつて芳香族多カルボン酸を得ている。一方大統 領原料政策委員会の報告によれば石炭の水添汇よる劳香 族化合物の合成も研究されパイロットプラントが硉設さ れたと言われている。従つて近い将来石炭系資源によ つてテリレン原料が充分得られる可能性はある様江思え るが，現状では価格的にな招研究を要する様である。

カーバイト，或は天然ガスからのアセチレンを原料と する方法は所謂レッぺの環化重合によつてシクロオクタ テトラエンを合成しこれを酸化してテレフタル酸誘導体 を得るすのであり，又環化共重合による DMT の合成 等も発表されているが, 収率,アセチレンの価格等の点よ り日本の現状では安価得る事は難しい样に思われる。

", 采知の如くイギリスでテリレンの工業化が遅れたのは 原料問題にあつたと言われているが，これはアメリカに 於て発表したペトロケミカルによつて解決された。即ち 石油の芳香族化によつてベンゼン，トルエン，キシレン の所謂 BTX フラクションが脂肪属炭化水素から合成さ れる様になつた。我国です各石油会社はプラットフオー マーの建設を行つているが，現状に於てはその規模は小 さく， 国産 p-キシレンは望めない有様であるが近い中 に供給される事が期待されている。

更に他の資源として植物成分特にパルプ製造廃液中の サルファイトテレピンから分離される $p$-シメンがある。 $p$-シメンの量は亜硫酸パルプの $0.1 \%$ 程度であつて我 国では約 $7 \mathrm{t} /$ day 程度にしかならず, 合成䄉維原料とし 
て補足的な意義しか見出せない事は残念である。 $p$-シメ ンの酸化については種々報告されているが ${ }^{2 \sim 6)}$, 最近発 行された井本稔編「新合成織維」とテレフタル酸及び DMT の製造とついて詳しく記されている。

\section{III ベンゼン及びトルエンを原料とする方法}

ベンゼン及びトルエンから DMT を合成するために その $p$-位に置換基を導入する方法として，その炭素源 を八ロゲン, スルフオン, 及びニトリル基等の活性置換 基を経て得るか, 又はアルキル化, クロロメチル化等に よつて直接に得るか，いずれかの方法がとられている。 これらの方法の中から工業的にも興味があると思われる ものについて記してみると，

(1)

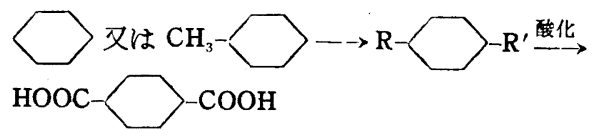

$\mathrm{R}, \mathrm{R}^{\prime}=\mathrm{Me}, \mathrm{Et}, i-\mathrm{Pr}$ 等

(2)

$$
\mathrm{Br}-\longrightarrow-\mathrm{Br} \frac{\mathrm{ClCOOC}_{2} \mathrm{H}_{5}}{\mathrm{NaHg}_{110^{\circ} \mathrm{C}}}
$$

(3)<smiles>O=C(O)C1CCC(C(=O)O)CC1</smiles>

文献 (8)

三井化学の特許 ${ }^{8)}$ ではジクロロベンゼン (o: $p=55$ : 45) 20 部, 水 20 部, ニッケルカーボニル 1 部, ヨード 1 部を高圧反応器中で $310^{\circ} \mathrm{C}$, 一酸化炭素を 200 気圧で 吹き込んで 30 分反応させるとフタル酸 9 部, テレフタ ル酸 8.5 部よりなる生成物を得る。一方 du Pont の特 許9)では $p$-ジクロロベンゼン $75 \mathrm{~g}$, ニッケルカーボニ ル $45 \mathrm{~g}$, 塩酸 $19 \mathrm{~g}$ を $310^{\circ} \mathrm{C}$ で一酸化炭素を $4300 \mathrm{psi}$ で 2 時間反応させる事によつて変化率 $20 \%$ で生成物を 得, 生成物中の $p$-ク口ロ安息香酸は $89.5 \%$, テレフタ ル酸は $10.5 \%$ である。

水の代りスメタノールを用いた時 ${ }^{101} は$ ，例えばニッケ ルカーボニル $17 \mathrm{~g}, p$-ジクロロベンゼン $30 \mathrm{~g}$, メタ, ール $70 \mathrm{~g}$ を銀ライニングした反応器中で $300^{\circ} \mathrm{C}$, 一酸 化炭素圧 280 気圧で 9.75 時間反応させると DMT $12.1 \mathrm{~g}$, テレフタル酸 $6.3 \mathrm{~g}$ を得る。

更に次の方法も発表されている。

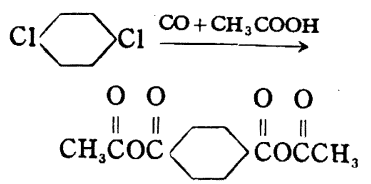

文献 (11)

（橉造式は特故の写しによる）。

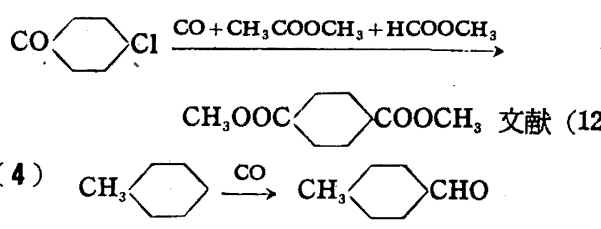

これは中間体としての $p$ ートルアルデヒドを合成する もので, 常法 ${ }^{13}$ では塩化第一銅, 塩化アルミニウムを 触媒として塩化水素- 一酸化炭素の混合ガスで合成する が, du Pont の特許 ${ }^{14)}$ ではトルエン 0.75 モル, HF 0.75 モル, $\mathrm{BF}_{3} 0.75$ モルをオートクレーブ中で $-32^{\circ} \mathrm{C}$ 亿冷却し 210 540 psi で一酸化炭素を吹込み 24 分間 反応させると変化率 $40.6 \%$ で p-トルアルデヒドが得 られると言う。

（5）側鎖の㙁素置換体を利用するるの この方法 はベンゼン及びトルエンをクロロメチル化する事により てキシレン誘導体に変え，てれからテレフタル酸及び DMT を合成するものであるが，これはヌキシレンを直 接塩素化 ${ }^{15)}$ する事によつて子行い得る。しかしこのトル エンを原料とするクロルメチル化の方法はトルエンに炭 素を導入する点に於て重要な方法と思われる。その概略 を第 1 図に示した。

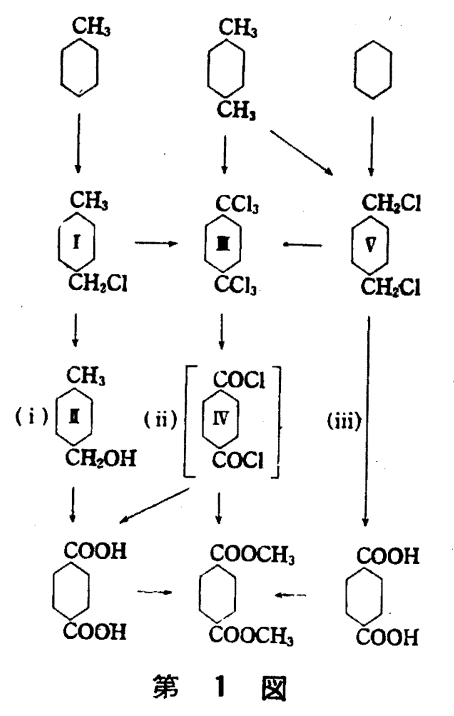

i） p-キシリルクロライドから 特許 ${ }^{16)}$ によると常 法によりトルエンをクロロメチル化して得た $p$-キシリ ルクロライド (I) を加水分解して $\boldsymbol{p}$-トリルカルビノー ル（II）を合成する。これをバナジン酸錫を触媒として $260^{\circ} \mathrm{C}$, 空間速度 3600 , アルコール / 空気 $=1 / 36$, 接胑 時間 1 秒で気相酸化するとテレフタル酸が得られると言 うが単なる特許にしか過ぎないるのかもしれない。 ii） p-キシレンへキサクロライドから テレフタル 


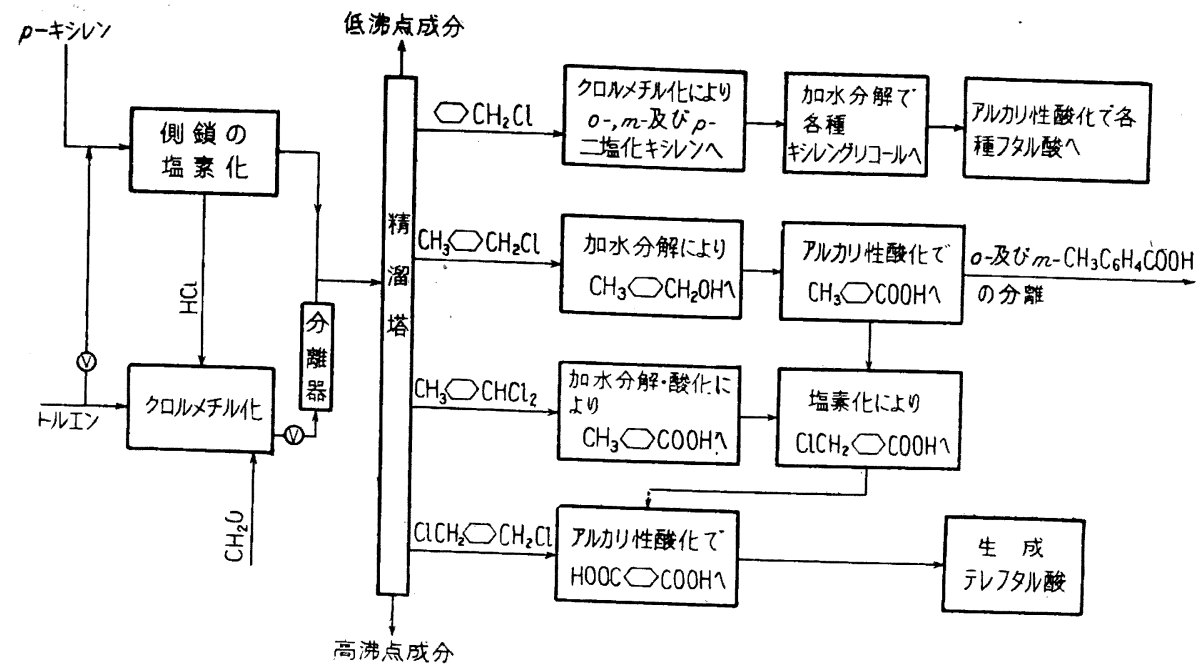

酸を製造するに当つてトルェンのクロロメチル化, 又は p-キシレンの塩素化による方法はすでにドイッで研究さ れていた事柄で PBリポート等 ${ }^{17}$ に見られるが, 戦後す ての方法が更に研究されている様であり空気酸化によら ぬ時はこれは相当重要性があると見られている ${ }^{18)} 。$

先ず $p$-キシレンヘキサクロライド (III) の合成であ るが, 原料中に混存する 0 -化合物は塩素化の際には立 体障害のため五塩化物にしかならぬのでベンジンで再結 晶する事によつて除き得る。かくて得られた (III) $6 \mathrm{~kg}$ 飞塩化第二鉄 $0.5 \mathrm{~g}$ を加兄 $135 \sim 140^{\circ} \mathrm{C}$ で水 $550 \mathrm{cc}$ を 8 時間にわたつて添加し, 更飞数時間 $140^{\circ} \mathrm{C}$ 亿保つ事 Кよつてテレフタル酸クロライド (IV) が殆んど定量的 に得られる ${ }^{17)}$ 。

最近の方法 ${ }^{18}$ では，(III）を $80 \%$ メタノール中で塩 化第二鉄及び硫酸を触媒としてエステル化する事によつ て DMT が得られると言われている。

iii） p-キシレンジクロライドから California Research Corporation (C.R.C. と略す) の特許 ${ }^{19}$ そよる と, p-キシレンの塩素化生成物を高温, 加圧下で苛性ソ 一ダ溶液で処理する事によつてテレフタル酸が得られ第 2 図の如きフローシートをあげている。

との特許には第 3 図の各工程についての反応条件が相 当詳しく記載してある。

、他の特許 ${ }^{20}$ 亿よれね゙これらの塩素誘導体を苛性ソー 外溶液中で $300 \sim 400^{\circ} \mathrm{C}$ で加圧空気酸化する事によつて すテレフタル酸が得られると言われている。

(6) その他の方法としては次の如き๖のがある。

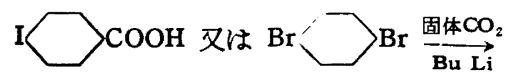

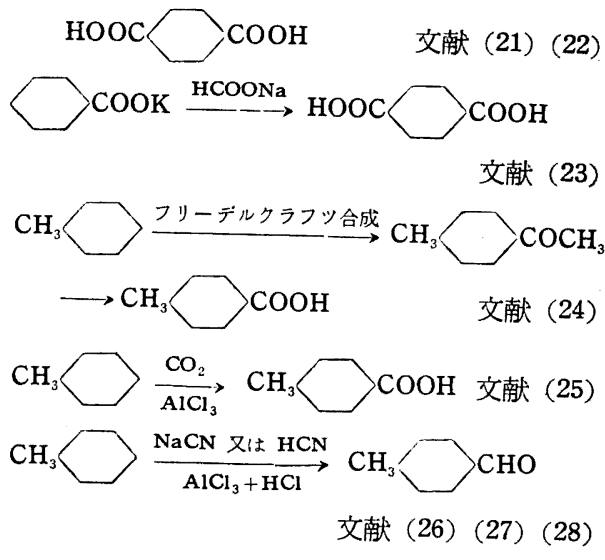

IV p-キシレン及び $\boldsymbol{p}$-ジアルキルベンゼシ を原料とする方法

現在工業的に行われているテレフタル酸又は DMT の 合成はその殆んぞが原料を $p$-キシレンに仰いでいる有 様であつて, 例えば du Pout はp-キシレンの硝酸酸化, I.C.I. は $p$-キシレンの空気酸化一硝酸酸化の併用では ないかと推定され, 又 Imhausen Werke 及び Hercules Powder Co. は $p$-キシレンの空気酸化 ${ }^{29)}$ であるとされ ている。

アメリカに於ける 1953 年度キシレンの生産量は 9 億 ポンドであつてその 83\% は石油化学によると言われ p-キシレンの生座は最近急激に増加している様であり年 間 1 億ポンドに近い生産があるのではないかと思われ る。一般に原油からの p-キシレンの生成比率は, 勿論 原油によつて異るわけであるが，0.4\%程度と言われて 
いるが，日本の石油工業の現状ではまとまつた量の $p$ キシレンを得る事は難しい椂である。最近Chemofining なる化学原料を主目的とする処理方法が報ぜられている が31)，その生成比率は第3 図の様炕なている。

p-キシレンの側鎖の酸化削としては, 過マンガン酸カ リ, クロム酸及び重クロム酸塩, 硝酸, 電解酸化 ${ }^{32 \sim 38}$, 空気, 及び其の他 ${ }^{39}$ があるが，これらの中で工業的に取 りあげ得ると考劣られるすのとしては主として硝酸酸化 と空気酸化であるろ。

硝酸酸化については一般に常圧酸化の場合には $p$-卜 リル酸までしか酸化されず5)40141)，現在 du Pont 及び I.C.I で行なわれていると推定される加圧硝酸酸化法に よつてテレフタル酸の工業生産が可能になつた ${ }^{42 \sim 45)}$ 。

しかし瀻維原料としての DMT は高純度を要求され， 硝酸酸化てよるテレフタル酸中には窒素として0.5\%の 不純物を含む ${ }^{42)}$ と言われているので硝酸酸化は好まし い方法であるとは考兄られな。

例をあげるど3)，p-キシレン $2.62 \mathrm{lb}$ をオートクレー ブ中に入れ $150 \sim 165^{\circ} \mathrm{C}$ に加熱する。この中へ $30 \%$ 硝 酸 $30 \mathrm{lb}$ を 22 分間に添加する。(100\% $\mathrm{HNO}_{3} / p$-xylene $=3.4 / 1)$ 。添加後温度を $180^{\circ} \mathrm{C}$ とし 15 分間 $200 \mathrm{lb}$ の
圧で反応させると収率 9396 でテレフタル酸が得られる。 （テレフタル酸の純度 83\%）

空気酸化による DMT 合成法が発展した現在に於て は硝酸酸化法は $\boldsymbol{p}$-キシンンを原料とする場合殊更新し く論議する重要性はなくなつた様に考えられる。

其の他の興味ある方法としてC.R.C.の特許 ${ }^{46)}$ がある。 これは酸化中間体である $p$-トリル酸を酸化するるので 反応は次の如く進むが，例党ば内容 $2.5 l$ のステンレス

$$
\begin{aligned}
\mathrm{CH}_{3} \longrightarrow \mathrm{COOH}+3 \mathrm{~S}+2 \mathrm{H}_{2} \mathrm{O} & \longrightarrow \\
\mathrm{HOOC} & \longrightarrow \mathrm{COOH}+3 \mathrm{H}_{2} \mathrm{~S}
\end{aligned}
$$

オートクレーブ中にトリル酸, 硫黄, 苛性ソーダ溶液を モル比で 1:4:1 亿なる様に入れ $600^{\circ} \mathrm{F} て ゙ 1$ 時間半反 応させる。(圧力 $2200 \mathrm{psi}$ ) これによつて変化率 $87 \%$ で フタル酸が得られると言う。

次汇空気酸化法としては，気相法 ${ }^{4 i \sim 55)}$ 及び液相法が あるが，気相法は工業的見地からすれば余り有利ではな い様なので記述は省略する。

\section{V p-キシレンの液相空気酸化}

テリレンの原料であるテレフタル酸及び DMT の製造

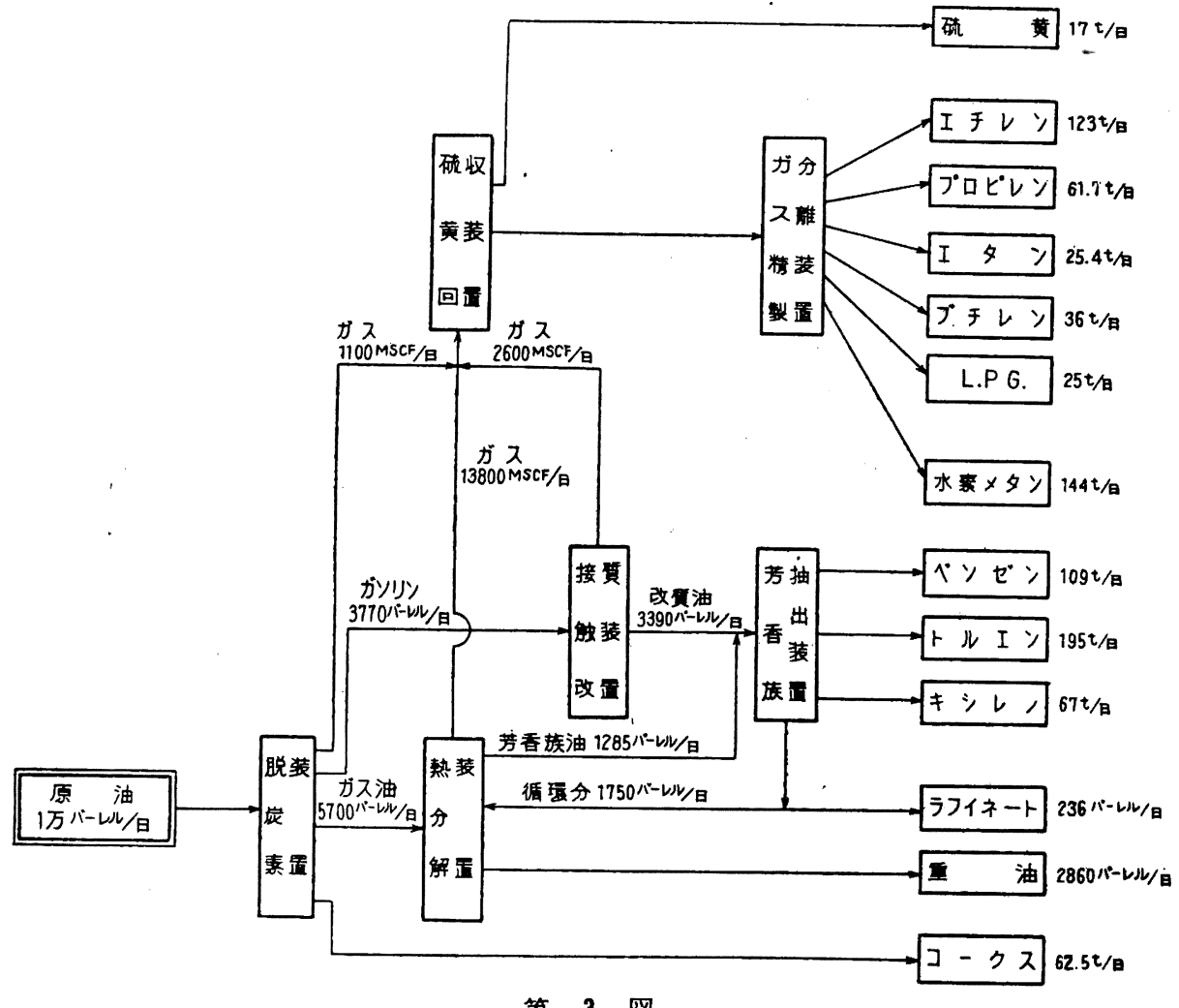

第 3 図 
が問頵次なつてか液相空気酸化に関して多方面で研究 が行われた様であつて特許面から見ても色々新しい方 法が発表され，その中でも Imhausen Werke 及び Hercules Powder Co. のトリル酸エステルを経由する 方法はすで業的生産の段階に達した。実に油溶性触

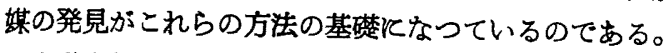

自動空気酸化反応の機構飞関しては古くは Bone $\mathrm{e}^{56,57}$, Stephens $^{58)}$ 等の説があつたが，今ではフリーラシカル による連鎖反応である事は疑 5 余地のない処で，Bell ${ }^{591}$ 等の提晿する理論が最も妥当なると考觉られている。

p-キシレンの場合も先ず $p$-キシリルハイドロパーオ キサイド'仿が生じ，これが分解してフリーラジカルを生 成し反応は進行するるのであるが，これら機構関して は綜説が発表されているので59761 64) 省略する。

今日までの空気酸化方式についての各種の特許を分類 して見ると，p-キシレンを一段でテレフタル酸へ酸化す る直接酸化法 ${ }^{65 \sim i 0)}$ と, $p$-キシレンを先ず $p$-トリル酸迄 酸化し，更めて $p$-トリル酸を酸化してテレフタル酸に する中間体を経由する酸化法と江分類出来る。

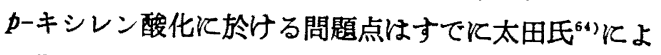
つて指摘された如く，第二番目のメチル基の酸化を如何 にして行うかと言う点にあり, 重点は第二段過程の方に ある。次に各方式について紹介する。

（1）直接酸化法 この方式によるすのとしてはI. C.I. とよつて発明された特許 ${ }^{\text {(5) }}$ がある。即ち反応器中 ヘp-キシレン 1000 に対してナフテン酸コバルト 20 割合で混合したるのを添加し， $130^{\circ} \mathrm{C} て ゙$ 空気を空間速度 200 で吹き込んで反応させる。反応器下部にテレフタル 酸が沈激してくる様になれば下のコックから反応液を抜 き出して固体を分離し港夜江新しいキシレンを添加して 循環反応させる。この様沉すれば反応液の“酸化活性 度” (Oxidative Activity) を減ずる事なく反応は連続 的飞進行し，仕込及 $p$-キシレン 100 亿対して固形物 90 艺得，この中の $77 \%$ はテレフタル酸であつたと言 5。

しかしこの特許は後で提出された日本特許 ${ }^{45}$ 中で修正 された。つまり上述の反応方式ではテレフタル酸は除去 されるが $p$-トリル酸の芳香族エステル， $p$-トリルアル デヒド等の酸化中間体及び副生物は除去されずに蓄積さ れ，反応を工業的規模に於て実施する際には，たと竞新 しい $p$-キシレンを連続的に添加しても反応液の 酸化活 生度を維持する事は極めて困難であるとして，第二段過 程を硝酸酸化する方法を提出している。

尚この酸化反応には凝平衡が存在するという説すある が反応物中のトリル酸濃度をある一定の值维持すれば
テレフタル酸が多く生成するという特許 ${ }^{70)}$ ある。例之 ば $p$-トリル酸 545 部, $p$-キシンン 106 部, $p$-トリル酸 コバルト 6.5 部の混合物を $250 \mathrm{psi}, 175^{\circ} \mathrm{C}$ で高速撜拌 しつつ空気酸化し, 反応中反応物を分析し, $p$-キシンン を添加する事によつて $p$-キシンン|p-トリル酸 $=0.07 / 1$ （モル比）飞なる様にすれば全反応物中 40 重量 \% の テレフタル酸を得る。

次に加圧直接酸化 ${ }^{66)}$ の例としては，擸拌器附き（1750 r.p.m) のステンレスオートクレーブK p-キシレン 500 $\mathrm{g}$, 水酸化コパルト $1.5 \mathrm{~g}, p$-トリル酸 $2.5 \mathrm{~g}$ を加え 160 $\sim 170^{\circ} \mathrm{C}, 200 \mathrm{psi}$ で空気を $1.5 \mathrm{ft}^{3} / \mathrm{hr}$ の割合で送入し て反応させると, 転化率 $10.3 \%$ でテレフタル酸が得ら れるが，これに誘起郕として四エチル鉊 ${ }^{67} 1.0 \mathrm{~g}$ 又は ヘキサクロルエタン ${ }^{68)} 1.0 \mathrm{~g}$ を加えて同樣に反応させる と転化率は $16.7 \%$ 及び $18.9 \%$ となる。

これらの特許では油溶性金属塩を使用していないが， 同特許江よると, $\mathrm{Co}, \mathrm{V}, \mathrm{Pb}, \mathrm{Ba}, \mathrm{Fe}, \mathrm{Mn}, \mathrm{Cr}$ 等の酸 化物及び水酸化物が触媒として有効であり, 反応条件下 ではこれらの水酸化物及び酸化物の大部分は, 反応生成 物である酸と塩を形成して（例えば $p$-トリル酸コバル 卜等になつて）油溶性となり，触媒作用を示すと述べら れている。

（2）中間体を経由する酸化法 更に下の様汇分類 出来る。

第一段過程 ( $\boldsymbol{p}$-キシンン $\rightarrow p$-トリル酸)

i ）稀橎郕なしの酸化 ${ }^{71 \sim 73)}$

ii）アルカリ性媒質に於ける酸化

iii）酸生媒質飞於ける酸化 ${ }^{76.77)}$

第二段過程（p-トリル酸 $\rightarrow$ テレフタル酸）

i）稀採郕なしの酸化 ${ }^{72}$

ii）アルカリ性媒質飞於故る酸化 ${ }^{78,79}$

iii）酸性媒質飞於ける酸化 ${ }^{80}$

iv） トリル酸誘導体の酸化 ${ }^{81 \sim 83}$

まず第一段過程である $p$-キシレンから $p$-トリル酸へ の酸化沉いて

i）稀釈剂なしの酸化 PB リポート 亿1) によれば， $p$-キシレン $1 \mathrm{~kg}$ に油溶性コパルト㙁 $1 \%$ を添加, $115^{\circ} \mathrm{C}$ で 20 30 時間空気を $50 \mathrm{l} / \mathrm{hr}$ の割合で吹込み反 応させると 50\% が酸化される。これを冷却して リル酸を分離するが，この時副生物は一次生成物として は $p$-トルアルデヒド, $p$-トリルカルビノール, 二次生成 物としてメチルベンジルトルエート $\left(\mathrm{CH}_{3} \mathrm{C}_{6} \mathrm{H}_{4} \mathrm{COOCH}_{2}\right.$ $\left.\mathrm{C}_{6} \mathrm{H}_{4} \mathrm{CH}_{3}\right)$ を生成する。

この例は常圧法であるが，加圧法の方が望ましいと思 われる。 
ii） アルカリ性媒質における酸化 古くSchrader ${ }^{74}$ 及び Fischer ${ }^{75)}$ は $p$-キシレン及び $p$-シメンを苛性り 一ダ溶液中で空気酸化を行い $p$-トリル酸及び少量のテ レフタル酸を得ている。

iii）酸性媒質における酸化 酸生媒質としては醋酸, $n$-酪酸年) 等があげられているが, du Pont の特許 ${ }^{77}$ に よればタンタルライニングした反応器中に混合キシレン $2360 \mathrm{~g}$, 醋酸 $130.6 \mathrm{~g}$, ジエチルケトン $3.7 \mathrm{~g}$, 醋酸コバ ルト $0.185 \mathrm{~g}$, 醋酸マンガン $0.185 \mathrm{~g}$ を添加し, 187〜 $202^{\circ} \mathrm{C}, 50$ 気圧で空気を $250 \mathrm{l} / \mathrm{hr}$ の割合で吹込み 2 時 間反応させる。反応後蒸溜により $75.7 \mathrm{~g}$ の未反応キシ レンを回収し，次の生成物を得る。即ちトリル酸 $50.3 \%$ フタル酸 $2.0 \%$, トリルアルコール $1.5 \%$ ，トリル酸エ ステル $8.1 \%$ ，トリルアルデヒド 5.790 である。

次第二段過程である $p$-トリル酸からテレフタル酸 への酸化について

i）稀积剂なしの酸化 C.R.C. の特許 ${ }^{22}$ では, 水分 離器及び空気吹込口を有するターボそキサー中で $p$-キ シレン $1455 \mathrm{~g}$ から空気酸化によつて転化率 $42.9 \%$ で pートリル酸を得, これを $475^{\circ} \mathrm{F}$, 無触媒で 8.5 時間酸素 酸化する。この時転化率は $30 \%$ 程度となり, 生成物を 冷却粉砕 95\% エターノールで抽出する事化よつて純度 95.5\%のテレフタル酸を得る。p-キシレンからテレフタ ル酸への総収率は 111.8 重量 㒸である。

ii）アルカリ性媒質における酸化 Monsanto の特 許 ${ }^{79}$ によれば触媒としては $\mathrm{Ag}, \mathrm{Pb}, \mathrm{Se}$ の酸化物又は 水酸化物で, $p$-トリル酸に対して0.05〜10\% 添加する。 アルカリとしては, 苛性ソーダ, 昔性カリ, 炭酸ソーダ

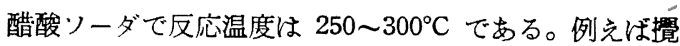
找器付きオートクレーブ中に水 $450 \mathrm{~g}$, 苛性ソーダ 73.5 g, pートリル酸 $100 \mathrm{~g}$ を添加し, 酸素圧を $700 \mathrm{psi}$ とし て $240^{\circ} \mathrm{C}, 6$ 時間反応させると, 反応生成物から収率 33.30 でテレフタル酸が得られ,同様にして $260 \sim 275^{\circ} \mathrm{C}$, 酸素圧 $1000 \mathrm{psi}, 1$ 時間では $63.5 \%, 260 \sim 270^{\circ} \mathrm{C}$, 酸素 圧 $1000 \mathrm{psi}, \mathrm{AgOH}$ 添加, 1 時間では $66.7 \circ$ となる。

iii）酸性媒質における酸化 du Pont の特許 ${ }^{80}$ 飞

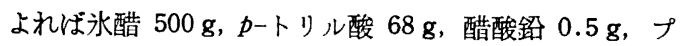
ロピオンアルデヒド $0.5 \mathrm{~g}$ ，エチルメチルケトン $0.5 \mathrm{~g}$ をオートクレーブ中で $180^{\circ} \mathrm{C}, 750 \sim 900 \mathrm{psi}$ で 3.5 時間 空気酸化する。この間廃ガス中の酸素は 12.4 15.8\% の間にある。反応混合物を $70^{\circ} \mathrm{C}$ で伶却滤過する事によ つてテレフタル酸 $17.7 \mathrm{~g}$ を得る。この際の転化率は 21.30 で, テレフタル酸の収率は 91.69 品でる。応 中廃ガス中の炭酸ガスは最高 3.6 多に達する。

iv）トリル酸誘揱体の酸化 前述の如く p-キシレン
酸化の問題点は第二段過程にあるが， $p$-トリル酸をその まっ酸化する方法では $p$-トリル酸り融点が高いために 反応操作上困難があり, 且又テレフタル酸の生成速度す 遅い。又アルカリ性媒質に於ける酸化では反応物がナト リウム塩となつて均質飞溶解するため変化率を上げ得る 利点はあるが，テレフタル酸と当量のアルカリ及び酸を 必要とするため必ずしる有利な方法とは言えず, 更に酸 性媒質中の酸化の場合も稀䣋剂の使用による有利さはあ まりない様である。従つて, テレフタル酸への酸化速度 を大とし，反応操作を容易ならしめるためには，触媒の 検討及びトリル酸誘導体の酸化を考劣ねばならぬが，こ れには Imhausen Werke 及び C.R.C. Kよつて発表 された注目すべき特許がある。向この工業化成功した Hercules Powder Co. は Imhausen Werke 及び C.R. C. の両社からライセンスを得ている。

Imhausen Werke ${ }^{81,82)}$ 及び C.R.C. ${ }^{82)}$ の特許は内容に 於ては殆んぞ同一であつて，いずれす p-トリル酸のメ チルエステルを液相空気酸化してテレフタル酸モノメチ ルエステルを得るすので, この場合核のメチル基は酸化 されるが，エステル基は酸化を受けないと言われてい る。

$$
\mathrm{CH}_{3} \longrightarrow \mathrm{COOCH}_{3} \longrightarrow \mathrm{HOOC} \longrightarrow \mathrm{COOCH}_{3}
$$

従つてこの方法を $p$-キシレンを原料として出発する 時は<smiles>CCCOC(=O)C1CCCCC1C(=O)OCCCCCCC(=O)OCC</smiles>

DMT の四段過程を経るので，一般には四段法と言わ れている。

先ず C.R.C. の特許では使用エステルとしては炭素 1〜4 の低級アルコールエステル, 特にメチルエステル が好ましく, 反応温度は $300 \sim 500^{\circ} \mathrm{F}$, 特に $350 \sim 420^{\circ} \mathrm{F}$, 反応圧は $200 \mathrm{psi}$ 迄, 触媒油溶性重金属㙁特飞 Cobalt 2-ethylhexanoate, Cobalt naphthenate, Cobalt toluate で濃度は $0.001 \sim 0.05 \%$ （Co 金属として）が適当であ る。この反応に於ては約 1 時間程度の誘導期が存在する が, これはベンツアルデヒド $2 \%$, 又は反応混合物を 2 \%添加する事によつて誘導期をなくす事が出来る。パー オキサイドの添加は効果が少ないと言われている。第 1 表に反応例を示す。

次に Imhausen Werke そよつて出願されたドイツ特 許によると一般にポリアルキルベンゼンを酸化すると， 第一のメチル基は容易に酸化されるが, 第二第三のメチ ル基は，そのま〉では酸化困難であつて，先に酸化され たメチル基を適当な誘導体に変えて酸化する事によつて 
第1表トリル酸エステルの酸化

\begin{tabular}{|c|c|c|c|c|c|}
\hline 实 No. & 1 & 2 & 3 & 6 & 7 \\
\hline 買性体 & 湿合(b) & 混合 & 混合 & 混合 & 混合 \\
\hline 時 間（時間） & 10.5 & 4.75 & 3.25 & 9.05 & 5.25 \\
\hline 温 度 $\left({ }^{\circ} \mathbf{F}\right)$ & 405 & 405 & 400 & 400 & 400 \\
\hline 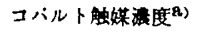 & 0.005 & 0.005 & 0.85 & 0.005 & 0.005 \\
\hline 添加トリル酸エステル & $\mathrm{Me}$ & Me & $\mathrm{Me}$ & Et & $i-\operatorname{Pr}$ \\
\hline$\cdot \quad(モ n)$ & 1.22 & 1.23 & 1.21 & 1.16 & 1.06 \\
\hline 回収 " & 0.30 & 0.27 & 0.47 & 0.19 & - \\
\hline 消贯 "(モル) & 0.92 & 0.94 & 0.74 & 0.97 & - \\
\hline 通過 酸索量（モル） & 4.70 & 2.53 & 1.67 & 2.06 & 1.64 \\
\hline 消费 "（モル) & 1.9 & 1.6 & 0.73 & 1.57 & 0.56 \\
\hline 発生 $\mathrm{CO}_{2}$ (モル) & 0.46 & 0.4 & 0.37 & 0.40 & 0.12 \\
\hline 生成 $\mathrm{H}_{2} \mathrm{O}$ （モル） & 1.11 & 1.22 & 0.50 & 1.36 & 0.50 \\
\hline 生成フタル酽（モル） & $0.64^{\mathrm{C})}$ & $0.66^{\mathrm{d})}$ & $0.31^{(s)}$ & $0.29 \mathrm{c})$ & - \\
\hline 収案 （モル\%） & 70 & 70 & 42.5 & 30.0 & - \\
\hline
\end{tabular}

a) コバルトしての重量 \% b) o， $m$ 及どっ体の混合

.c) モノェステルとして

d) ジェステルとして

順調に酸化されると述へている。以下数種の例を示す。 pートリル酸メチルエステル $1000 \mathrm{~g}$ 亿炭素数 6 10を 有する混合脂肪酸のコパルト塩 $2 \mathrm{~g}$ を添加し， $120^{\circ} \mathrm{C}$ で空気流量 $1.5 \mathrm{l} / \mathrm{min}$ で 8 時間酸化する。反応後 $30^{\circ} \mathrm{C}$

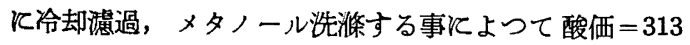
(理論值 311.5), 眮化価 $=621$ (理論値 623), 融点 $217^{\circ} \mathrm{C}$ のテレフタル酸モノエステル $240 \mathrm{~g}$ を得る。

次飞大規模で行了場合, 温度調節器, 空気吹込口, 水 分離器附摆流冷却器をつけた内容 $100 l$ の酸化槽飞炭素 数 6 10 の混合脂肪酸のコパルト塩 $120 \mathrm{~g}$ 及び工業用 キシンン $60 \mathrm{~kg}$ を添加し, $130 \sim 140^{\circ} \mathrm{C}$, 空気流量 $1.5 \sim$ $2 \mathrm{~m}^{3} / \mathrm{hr}$ で酸化する。反応混合物の酸価が約 250 飞なつ てから連続的に $60 \mathrm{~kg} / \mathrm{hr}$ の割合で反応液を取り出し, $20^{\circ} \mathrm{C}$ 飞冷却乙，遠心分離機で結晶を分離する。この時 $8 \mathrm{~kg} / \mathrm{hr}$ の割合で酸化生成物を得る。これを $8 \mathrm{~kg} / \mathrm{hr} の$ 新しいキシレンで洗深し，先の滤液と合わせて酸化槽に 還流させて反応槽内の酸価を常に 200〜280 飞保つ。か くて得られたトリル酸を常法によりエステル化して, ト リル酸メチルとしトリル酸メチル $1 \mathrm{~kg}$ に対して混合 脂肪酸コバルト塩 $2 \mathrm{~g}$ の割合で添加し, $140^{\circ} \mathrm{C}$ 空気流 量 $1.5 \mathrm{l} / \mathrm{min} / \mathrm{kg}$ ester で酸化する。この酸化には内容 $100 l$ の反応槽を用い，これと $60 \mathrm{~kg}$ のエステルを添加 し, 酸価 100 150 亿達した後, 連続的に反応混合物を 取り出し， $30^{\circ} \mathrm{C}$ 飞冷却遠心分離してテレフタル酸モ， メチルエステルを $6 \mathrm{~kg} / \mathrm{hr}$ の割合で得る。濾液には $6 \mathrm{~kg} / \mathrm{hr}$ の新しいエステルを添加して再び酸化槽へ戻す。

同特許には， 0 - 及び $m-$ トリル酸エステルの酸化例 があり, 又エステル化化用いるアルコールる，メタノ一 ルイ限らず芳香族アルコール等種々の例がある。例えば $p$-トリル酸の $p$ - トリルカルビノールエステルを酸化し た場合には，テレフタル酸の $p$-カルボキシベンジルア ルコールエステルになり,

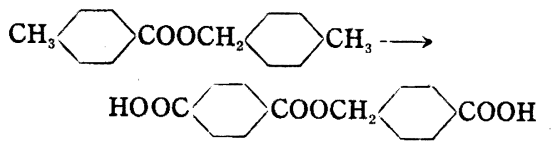

エチレングリコールエステルの場合は次の如くなると言 弓。

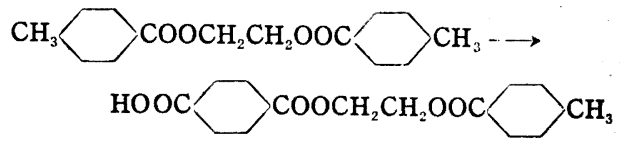

更にエステル以外の誘導体，例えば無水 $p$-トリル酸 の酸化の例をあげているが，興味ある例として Pseudocumol の酸化すある。

\section{VI テレフタル酸の精製及びエステル化}

今迄述へてきた方法によつてテレフタル酸を得た場合 合成織維原料としてトリル酸の存在は好ましくないので 完全に除去しなければならない。これに関しては $2,3 の$ 特許 $^{84,85)}$ があるが，例えば ${ }^{84)}$ pートリル酸 $6.7 \%$ を合む 不純テレフタル酸 $100 \mathrm{~g}$, 水 2000 c.c. をオートクレー ブに入れ， $175^{\circ} \mathrm{C}, 100 \mathrm{psi}$ で擤找する。1 時間半後加 圧濾過し，沈澱をアルカリで再沈澱させると殆んど純粋 のテレフタル酸が得られる。

次にテレフタル酸のエステル化に関しては特許が少し あるが ${ }^{65,86,87)}$ 省略する。

\section{VII む す び}

以上ベンゼン，トルエン及びキシレンを中心をする DMT の各種の合成法について述へたが， p-キシンンの 空気酸化法(特に四段法)が有利ではないかと思われる。

現在 $p$-キシレンは 200 円 $/ \mathrm{kg}$ 程度であり, 又 Hercules Powder Co. の DMTは 70 80 セント/1b で, 将来年産 5000 万封度になれば DMT の価格も 45 55 セント/1b に下るだろうと言われている。

我国の石油化学工業が乾道棌乗り, 国産 $p$-キシンン の生産が開始される日の一日る早からん事を望む次第で ある。

(昭和 30 年 2 月 14 日受理)

\section{交献}

1）長沢, 松沢, 吉田：日化第六年会講演要旨集, 51 頁 (1953.4)

2) Sensemann, Itubbs : Ind. Eng. Chem., 24, 1184 (1932)

3）增尾, 加藤 : 工化, 55, 166 (1952)

4) 井本等：工化， 57，458 (1954) 
5）井本等：工化，57，460（1954）

6) 岡田, 伏崎: 工化, 57, 301 (1954)

7) Bomz: Ber., 18, 2305 (1885)

8）三井化学：日特公告, 昭 27-2424 (1952.7.1)

9) du Pont : U.S.P. 2565461 (1951.8.28)

10) du Pont : U.S.P. 2565462 (1951.8.28)

11) du Pont : U.S.P. 2565463 (1951.8.28)

12) du Pont : U.S.P. 2565464 (1951.8.28)

13）例兑ば Colemann \& Craig：邦訳 Org. Syn. 合 冊第 2773 頁等

14) du Pont : U.S.P. 2485237 (1949.11.18)

15）例兑は du Pont : B.P. 583643 (1946.12.23)

16) Gaslight \& Coke Co. : B.P. 644707 (1950.10. 18)

17) " : P.B. 80376 (BIOS 1149)

18) " : British Rayon \& Silk Journal, 358, 71 (1954)

19) C.R.C. : U.S.P. 2610211 (1952.9.9)

20) C.R.C. : U.S.P. $2563802(1951.8 .14)$

21) Gilman et al :J. Am. Chem. Soc., 70, 4177 (1948)

22) " : J. Am. Chem. Soc., 69, 1937 (1947)

23) Richter : Ber., 6, 877 (1873)

24）例总ば Kölsh : Org. Syn., 26, 95 (1946)

25) I. G. : F.P., 664611 (1928.11.26)

26) Hinke et al $: J$. Chem. Soc., 2793 (1932)

27) I.C.I. : B.P. 397124 (1933.8.15)

28) Niedzielski, Nord : J. Org. Chem., 8, 147 (1943)

29) " : Chem. Eng. News, 500 (1954.2.8)

30) " : Petr. Refiner, 33, 128 (1954)

31) " : Petr. Proce., 1070 (1954)

32) Low, Perkin: Chem. Zent., I 359 (1905)

33) Fichter et al : Helv. Chim. Acta, 4, 935 (1921)

34) " : Helv. Chim. Acta, 9, 1097 (1926)

35)." : Ber., 47, 2015 (1914)

36) Labharat : Beilstein IX Haupt 841

37) Allmard et al : Trans. Faraday Soc., 23, 641 (1870)

38) Fichter et al : Helv. Chim. Acta, 17, 717(1934)

39）例光ば Sultanov et al: Chem. Abst., 42,880 (1948)

40）例克ば Fittig \& Glinzen: Ann., 136, 311(1865); Tuley \& Marvel : Org, Syn. 27, 86 (1947)

41) 井本等：日化第七年会講演要旨集 103 (1954.4)

42) Aktiebolaget Bofers : B.P. 662139 (1951.12.5)

43) du Pont : B.P. 655074 (1951.7.11)

44) I.C.I. : 日特公告, 昭 29-826 (29.2.18)

45) I.C.I. : 日特公告, 昭 29-1985 (29.4.14)

46) C.R.C. : U.S.P. $2587666(1952.3 .4)$

47) Sensemann et al : Ind. Eng. Chem., 23, 1129 (1931)

48) Wilken : Chem. Abst., 26, 5406 (1932)

49) Schoen et al:Chem. Abst., 44, 1539 (1950)
50) Rafikav, Suvorov : Chem. Abst., 47, 2142 (1953)

51) Infiesta et al : Chem. Abst., 47, 3304 (1953)

52) Gasten, Charlot : Chem. Abst., 21, 5726 (1933)

53) Borgmann et al : J. Org. Chem., 17, 1291(1952)

54) Charlot: Chem. Abst., 27, 3454 (1933)

55) " : Chem. Abst., 29, 1314 (1935)

56) Bone, Drugman : Proc. Roy. Soc. (London), 20, 127 (1904)

57) Bone, Stocking : Proc. Roy. Soc. (London), 20, 106 (1904)

58) Stephens : J. Am. Chem. Soc., 48, 1824,2920 (1926); 50, 2523 (1928)

59) Bell : Disc. Faraday. Soc., 10, 242 (1951)

60) Hock, Lang: Ber., 76, 169 (1943)

61) Bell : Trans. Faraday Soc., 42, 101 395(1946)

62) Frank: Chem. Rev., 49, 156 (1949)

63）太田：高圧ガス協会誌，17，145（1953）

64) 太田：本誌, 12, 341 (1954)

65) I.C.I. : B.P. $623836(1949.5 .24)$

66) Monsanto Chemical Co. : U.S.P. 2552267(1951. 5.8)

67) " : U.S.P. 2552278 ( "

68) " : U.S.P. $2552268(")$

69) " : B.P. 680571 (1952.10.8)

70) N.V de Bataatsche Petroleum Maatschappij : B.P. 681455 (1952.10.22)

71) I.G. : P.B. 565 (1941.4.29)

72) C.R.C. : B.P. $666709(1952.2 .20)$

73) N.V de Bataatsche Petroleum Maatschappij : Dutch. P. 63989

74) Schrader : Abh. Kenntnis Kohle, 4, 319 , 129

75) Fischer : D.R.P. 364442 (1922.11.25)

76) Emerson et al : J. Am. Chem. Soc., 71, 1742 (1949)

77) du Pont : U.S.P. 2245528 (1941.6.10)

78) Emerson et al : J. Org. Chem., 16, 1839 (1951)

79) Monsanto Chemical Co. : U.S.P. 2559147 (1951. 7.3)

80) du Pont : U.S.P. 2479067 (1949.8.16)

81) Imbausen Werke：ドイッ特許公告 I 4030 IVd/120 (1951.4.12 出願)（1953.4.16 公告）及 びその追加特竍

82) Imbausen Werke：ドイッ特許公告 I 4137 $\mathrm{IVd} / 120$ (1951.4.14 出願)（1953.4.16 公告）及 びその追加特許

83) C.R.C. : U.S.P. 2653165 (1953.9.22)

84) Monsanto Chemical Co. : U.S.P. 2572575 (1951.10.23)

85) " : U.S.P. $2572710(1951.10 .23)$

86) I.C.I. : B.P. 684334 (1952.12.17)

87) du Pont : U.S.P. 2459014 (1949.1.11) 